1992

\title{
Doing the Right Thing?: Toward a Postmodern Politics
}

\author{
Allan C. Hutchinson \\ Osgoode Hall Law School of York University, ahutchinson@osgoode.yorku.ca
}

Source Publication:

Law and Society Review. Volume 26, Number 4 (1992), p. 773-788.

Follow this and additional works at: https://digitalcommons.osgoode.yorku.ca/scholarly_works (c) (1) $(9)$

This work is licensed under a Creative Commons Attribution-Noncommercial-No Derivative Works 4.0 License.

\section{Recommended Citation}

Hutchinson, Allan C. "Doing the Right Thing?: Toward a Postmodern Politics." Law and Society Review 26.4 (1992): 773-788.

This Commentary is brought to you for free and open access by the Faculty Scholarship at Osgoode Digital Commons. It has been accepted for inclusion in Articles \& Book Chapters by an authorized administrator of Osgoode Digital Commons. 


\section{A Postmodern's Hart: Taking Rules Sceptically}

\section{Allan C. Hutchinson*}

It is only shallow people who do not judge by appearances. The mystery of the world is the visible, not the invisible.

Oscar Wilde

Although considered somewhat passe in the recherche circles of jurisprudential scholarship, H.L.A. Hart's view of law as basically a ruleapplying activity remains the guiding theme of many legal practitioners and doctrinal scholars. The fact that his writings are no longer thought of as innovative or exceptional is only testament to their pervasive acceptance as part and parcel of what it is to be and think like a lawyer. Of course, this should not be surprising. His work was informed by the Austin -Wittgenstein imperative that good philosophy was simply making sense of people's daily linguistic practices: The Concept of Law was offered as 'an essay in descriptive sociology.' ${ }^{1}$ As such, his juristic studies recommended themselves to the practical mind of the common lawyer; there was an intuitive and reassuring fit between what lawyers thought they were doing and what they were told that they should be doing. The fact that Bart's uncluttered writings also justified and set to rest any qualms about the legitimacy of lawyers' and judges' roles in a liberal democracy also helped. Showcased by the elegant simplicity of his writing, Hart's elevation of legal common sense to the status of jurisprudential theory is both his greatest strength and his greatest weakness. ${ }^{2}$

Over thirty years after the publication of his majestic monograph, Hart has

\footnotetext{
* Professor and Associate Dean, Osgoode Hall Law School, York University, Toronto.

I would like to thank Harry Arthurs, Adam Bernstein, Richard Devlin, Howard Goldstein, Les Green, Rod Macdonald, Pam Marshall, Francis Mootz III, Sid Peck, Lisa Philipps, Richard Posner and Jim Smith for their critical encouragement, and Wendy Rambo for her technical assistance.
} 
posthumously rejoined the debate over the nature of law and adjudication. In a new and previously unpublished Postscript, incorporated in a second edition, Hart responds to some of his old adversaries, like Lon L. Fuller, Ronald Dworkin and John Finnis. In the process he adds a new spark to the debate and stokes the flame of analytical jurisprudence. While the differences between their positions and his own are importantHart contends that they are not as great or significant as many have come to believe. With characteristic equanimity and balance, Hart maintains that, shorn of exaggeration and caricature, there is much to recommend his adversaries: the problem lies not so much in their basic tenets, but in their hegemonic tendencies. Nevertheless, the postscript is a posthumous and unequivocal affirmation of Hart's own special brand of analytical jurisprudence that law and morality are best kept separate; that rules are the heart and soul of the legal process; and that adjudication has an inescapable element of choice. ${ }^{3}$

This essay proceeds on the raison d'etre that the past and its heroes are better respected through active engagement than through passive veneration. I want to put a revived Hart to work in the hectic world of contemporary concerns rather than leave him to be admired as an historical curiosity in the jurisprudential Hall of Fame. Such an undertaking can illuminate a very different Hart from the one caricatured in contemporary legal literature. Rather than be the country bumpkin to contemporary theory's urbane sages, he appears as a much more prescient and balanced theorist. To do this, I offer a postmodern reading of Hart; it is more a review than a review. By this, I do not mean that I will attempt to demonstrate that Hart was really a postmodernist at heart (although such a challenge is tempting). Instead, I will read Hart from an avowedly postmodern perspective - 
the fact that some of my conclusions may not be seen lo fit snugly with those that many think are crucial to the Hartian canon is beside the point.

The critical focus of this postmodern rendition is the always topical and perennially contested notion of what it means to take rules seriously. Working with Hart's mature theory, I will follow through, more fully than he did, on his primary insight that legal language is a social activity that depends on convention and context for meaning. As convention and context are never historically stable and always socially contestable, I argue that the meaning and application of legal rules cannot be put beyond the possibility of disputation or the need for defence. In defending this view of law as an incorrigibly indeterminate exercise, I will not take Hart's theory lightly, but actually take more seriously than he did his remark that 'rules cannot provide for their own application, and even in the clearest case a human being must apply them. ${ }^{14}$ And this is no bad democratic thing. In a society that aspires to more popular involvement and less elite control, rules are taken most seriously when they are treated most sceptically. Consequently, by pursuing this postmodern commitment, I will be better able to defend a Hartian-inspired sceptical thesis against the contending triad of contemporary jurisprudential approaches the arch-positivists, the neo-naturalists and the so-called nihilists.

This article is divided into three main sections. In the first, I locate Hart's positivistic account of adjudication within the configurations of contemporary jurisprudential debate that Hart's writings themselves helped to establish. The second section has a threefold structure: the first part unearths the linguistic footings of Ordinary Language philosophy on which Hart built his juristic edifice; the second shifts the critical emphasis from Hart's concern with 'textual 
ambiguity' to a more radical exposure of law's 'structural indeterminacy'; and the third gives a more practical rendering of that theoretical critique. In the third section, I play out the implications of this shift for the resolution of easy cases and for the practice of a sceptical judging. Finally, in a short conclusion, I draw together the strands of the sceptical argument and consider their combined effect on contemporary legal theorising. Throughout, I use Hart's famous example of the rule that 'no vehicles may be taken into the park' ${ }^{5}$ to illustrate and test the force of Hart's and my own general claims.

\section{The Hart of the matter}

Throughout Hart's diverse oeuvre, the connecting thread is his positivistic insistence that law and morality are best kept separate if the study of either is to be profitable and instructive. He has played a leading role in the three major debates in jurisprudence over the last fifty years. ${ }^{6} \mathrm{I}$ intend to concentrate on the third of these exchanges about the nature of adjudication and, in particular, the operation and limits of rule application as a method of legal decisionmaking how is it possible to get beyond a discredited formalism without turning judging into an open-ended exercise in ideological wrangling? Hart's prominence in this debate is ironic in that he later concluded that he said 'far too little about the topic of adjudication and legal reasoning. ${ }^{17}$ Indeed, the main thrust of his work is to present a more sophisticated theory of positivism than had hitherto been available and in which an explanation of adjudication would only be a small part. As such, The Concept of Law captures a special kind of positivism; the fact that it is now considered the positivistic 
account of law should not blind contemporary readers to its original novelty and controversiality. As well as believing that there are no noncontingent connections between Jaw and morality, Hart crafted a style of legal positivism that was more normative in content than Austin's and more pluralist in scope than Bentham's. ${ }^{8}$ However, rather than range broadly across the whole Hartian positivistic terrain, I will only touch upon such general themes as they relate specifically to adjudication and rule application. Moreover, in light of the widespread familiarity with Hart's work, my initial introduction will be brief and to the sceptical point.

\section{A good night's sleep}

Hart's concern is not with the internal perspective of how and why lawyers (and citizens) do what they do in particular legal cultures, but that of an external observer of law and legal systems generally. However, while theorists need not endorse the viewpoint of participants in the system to be understood, he does recognise that it is essential that theorists record the participants' normative views and commitments: 'description may still be description, even when what is described is an evaluation. ${ }^{19}$ As such, although his theoretical stance is resolutely external, Hart's positivism is of a soft variety. He does not maintain that the truth of legal propositions is reducible to bare historical facts, but acknowledges that values can be fully implicated: 'the existence and content of law can be identified by reference to the social sources of law ... without reference to morality except where the law thus identified has itself incorporated moral criteria for the 
identification of law. '10 Within these positivistic parameters, Hart depicts law as a functional and sophisticated system of rules the obligation-imposing primary rules that comprise the bulk of substantive legal doctrine, like criminal and contract law, and the authority-conferring secondary rules that distribute institutional power and jurisdiction, between legislatures and courts for example, over the creation and enforcement of the primary rules. In both cases, in keeping with his general theoretical perspective, Hart insisted that rules had to be distinguished from merely observable regularities of behaviour. For participants in the system, rules operate 'as the basis for claims, demands, admissions, criticism or punishment' and 'the violation of a rule is not merely a basis for the prediction that a hostile reaction will follow but as reason for hostility.' ${ }^{11}$ Without reference to this internal attitude that lawyers and citizens exhibit towards rules, a vital element of jurisprudential understanding would be lost. In the Hartian scheme of things, therefore, a cogent explanation of legal obligation is as much about attitude and acceptance as it is about fate and fiat.

Against this analytical backdrop, Hart developed a suggestive account of adjudication; it was a description of what occurs, not a prescription for what might or should occur. In typical fashion, he made a virtue of compromise. Presenting a reasoned and reasonable account of modern judging, he unashamedly sought to inhabit a middle-ground between formalist pitfalls and realist excesses: 'legal theory ... is apt either to ignore or to exaggerate the indeterminacies of legal rules.' ${ }^{12}$ Almost all commentators accepted that the realist account of adjudication 
'that judges always make and never find the law' was a nightmare to be avoided. Instead, debate was joined over the extent to which the noble dream of a formalist faith 'that Uudges] never make it' could be revived and revised. Throughout his contribution, Hart accepted that, while these 'illusions ... have much of value to teach the jurist in his waking hours,' ${ }^{13}$ the sensible lawyer will settle for a good night's sleep. He wanted to ensure that legal theory would abandon some of its more recent nocturnal fantasies so that legal practice would be able to get on with its day job in a refreshed and undistracted way.

Hart's patented jurisprudential formula for a legal good night's sleep is prosaic and pragmatic. While not claiming to offer a full-blown theory of adjudication, he considered rule application to be at the heart of the judicial task. Empowered to apply rules in order to resolve disputes between conflicting citizens, the hallmark of 'good' judges is their ability to identify the extant rules of the legal system and apply them to concrete situations. Nonetheless, this craft is not a purely technical or logical exercise. In a famous phrase, Hart argued that law has an 'open texture. "4 Because law, like language, is an entirely conventional affair and convention is neither gapless nor precise, this system of rules cannot be complete or comprehensive: some cases, therefore, will be 'not merely ... controversial in the sense that reasonable and informed lawyers may disagree about which answer is legally correct, but the law is fundamentally incomplete' (p 252). Consequently, these so-called 'hard cases' will invoke and require non-conventional decisionmaking processes. In fulfilling their duties, judges have to call on a variety of 
analytical skills and reasoning techniques: they act inductively when they extract rules from a line of past cases; they act deductively when they apply the inductively-extracted rule to the case in point; and they act politically when the inductively-extracted rule or its deductive application is uncertain or difficult. In this unpretentious account of judging, indeterminacy is something that pervades the judicial task, but it is always relative, marginal and not to be exaggerated. Accordingly, Hartian judges are not mindless automatons, Delphic oracles, wellmeaning simpletons, rampant legislators or cynical manipulators; they struggle to do justice in a way that respects rules without becoming enslaved to them. To the chagrin of the dogmatist and the true believer, they are 'men [and women], not gods' nor, it might be added, beasts. ${ }^{15}$

The first stage of Hartian adjudication is the inductive extraction of the appropriate rule; this is the precedential soul of the common law. Although there are 'a vast number of determinate rules' and this exercise will be productive of 'very little doubt,' Hart concedes that 'any honest description' will recognise considerable leeway for judicial involvement. ${ }^{16}$ Consequently, even at this first stage, indeterminacy is a characteristic feature of the adjudicative process -there is no one correct or authoritative method for determining the relevant precedent from among the many competing lines of cases, the rule for which a particular precedent stands, the precise verbal formulation of that rule, or the exceptions to that rule.

Having formulated the relevant rule (and its exceptions) with sufficient precision, the judge must then set about applying that rule to the facts of the 
case. This is the dynamic hub of the judicial undertaking. Neither absolute faith in the dispositive force of rules nor arbitrary disregard of them are part of the Hartian dialectic. While rule application is not a purely mechanical or logical operation, a genuine commitment to its consistent practice means that 'human conduct is made in some sense non-optional or obligatory. ${ }^{17}$ To apply a rule is not to make routine recourse to the consequences that attend such an application. Whenever one regularly does so, it undermines the practice and legitimacy of rule application generally: the judge ceases to be engaged in rule application, but is instead making a post hoc resort to the rule as a justification for a particular consequence which is compatible with the rule and which is not offensive as a matter of justice. For Hart, although an attention to consequences may be required in some cases, this is better done openly rather than under the pretence of rule application:

None the less, the life of the law consists to a very large extent in the guidance both of officials and private individuals by determinate rules which, unlike the applications of variable standards, do not require from them a fresh judgment from case to case. This salient fact of social life remains true, even though uncertainties may break out as to the applicability of any rule (whether written or communicated by precedent) to a concrete case. Here at the margin of rules and in the fields left open by the theory of precedents, the courts perform a rule-producing elaboration of variable standards. ${ }^{18}$

While the parameters and sources of this rule-producing responsibility have varied across the Hartian canon, his mature advice was that this power to legislate interstitially is not to be performed in a vacuum or done in an arbitrary or ideological way. When legal rules fail or run out, judges are not somehow out on their own but are subject to 'a wide variety of individual and 
social interests, social and political aims, and standards of morality and justice' ${ }^{19}$ that are encompassed in the working norms of legal doctrine. Indeed, it is the development and refinement of these 'criteria of relevance and closeness of resemblance... [that] characterise whatever is specific or peculiar in legal reasoning. ' 20 While there is no uniquely correct result, judicial choice is a rational and constrained process in which 'many decisions can be clearly ruled out as incorrect' ${ }^{21}$ and in which the failure to ensure real or idealised unanimity among judges is not fatal.

In the most important part of The Concept of Law's new postscript, Hart accepts that Dworkinesque principles are indeed part of the law, but denies that there is any sharp contrast between non-conclusive principles and all-ornothing rules: 'the distinction is a matter of degree. ${ }^{122}$ However, Hart does not believe that positivism is devastated by this concession because, when properly understood, a legal system's ultimate criteria of legal validity the rule of recognition can easily and legitimately accommodate moral values. That having been said, he insists that there is little to distinguish Dworkin's holistic interpretive criterion of legal integrity from his own recommended judicial way of proceeding. Judges must still offer general justificatory reasons for their decisions and, often proceeding by analogy, 'ensure that the new law they make, though it is new law, is in accordance with principles or underpinning reasons recognised as already having footing in the existing law. ${ }^{23}$ Nevertheless, even the most Herculean of judges will occasionally have to fall back on their own moral instincts and political beliefs: 
present themselves and a judge will often have to choose between them, relying, like a conscientious legislator, on his sense of what is best and not on any already established order of priorities prescribed for him by law. ${ }^{24}$

While Hartian judges might become adept at the independent crafts of rule application and rule production, the acid test of the truly gifted Hartian judges is their astuteness of knowing when to move from rule application to rule production. While this does not lend itself to formulaic instruction or structured learning, Hart does rely on the heuristic distinction between 'clear cases' and 'hard cases' to guide the perplexed judge through this critical maze and to maintain some chance of a good night's sleep. However, this instruction is somewhat empty as he admits that it is a matter of considerable difficulty to provide an exhaustive account of what makes a 'clear case' clear and what makes a 'hard case' hard. Nevertheless, he observes, somewhat tautologically, that clear cases are those occasions on which there is general agreement and very little doubt that the facts in issue obviously fall within the meaning and scope of a rule. Hard cases, therefore, must be those cases in which such general agreement is lacking and there are real doubts about the applicability of a rule. As with nearly all of Hart's work, the distinction is not so much a matter of conceptual analysis, but an observed fact about the empirical behaviour of judges and the functional operation of language:

Even when verbally formulated general rules are used, uncertainties as to the form of behaviour required by them may break out in particular concrete cases. Particular fact situations do not await us already marked off from each other and labelled as instances of the general rule, the application of which is in question; nor can the rule itself step forward to claim its own instances. In all fields of experience, not only that of rules, there is a limit, inherent in the nature of language, to the guidance which general language can provide. 
There will indeed be plain cases constantly recurring in similar contexts to which general expressions are clearly applicable ('If anything is a vehicle a motor car is one'), but there will also be cases where it is not clear whether they apply or not. ('Does "vehicle" used here include bicycles, airplanes, roller skates?') ${ }^{25}$

Again, however, Hart has not been entirely consistent about the empirical distribution of these clear and hard cases or, therefore, about the extent to which judicial choice is present and unavoidable. While he began with the opinion in 1958 that 'how rare ... [and] how exceptional is this feeling that one way of deciding a case is imposed upon us as the only natural or rational elaboration of some rule' and that the language of choice 'better conveys the realities of the situation,' he appears to have repudiated that view by 1983 and settled on the conclusion that the standard resort to rule application occurred 'very often' and was the primary device for legitimate adjudication. ${ }^{26}$ It seems to follow, therefore, that while Hart contends that 'a margin of uncertainty should be tolerated and indeed welcomed, ${ }^{27}$ he is also confirming that, for the positivist claim to hold true, there must be an operational degree of certainty. This conclusion seems vital if Hart is to maintain the integrity and validity of his accounts of law generally and judging in particular. Without a critical mass of standard meanings and settled rules, the very idea that rules would control judicial decisions, that there exists an actual body of workable rules, that such rul/es would command authoritative conformity, that judging is something less than legislative policy-making, and that there is some meaningful distinction between the law as it is and the law as it ought to be, would all be lost. For Hart, therefore, while legal theory and training will understandably be occupied with the penumbra, 'preoccupation with the penumbra is ... as rich a source of confusion ... as 
[preoccupation with] formalism. ${ }^{28}$

Of course, the fact that rules are not always dispositive of cases or that there is considerable scope for judicial choice and innovation is not presented by Hart as a matter of genuine concern. Indeed, he welcomes the fact that there is an inevitable and relative indeterminacy or open texture in the law: the loss of complete certainty and predictability is the price that has to be paid for the law being flexible enough to handle unanticipated cases in a fair and just manner. The challenge for both the judge and jurist is to strike an appropriate and manageable balance between the rule application of clear cases and the rule production of hard cases such that certainty is not sacrificed entirely to particularised flexibility. On this issue, Hart is adamant that, if clear cases did not comprise the bulk of adjudicated decisions, 'we should not attach significance and value to them or think of such decisions as reached through a rational process. ${ }^{29}$ Accordingly, Hart's writings present judging as a balanced and judicious affair it is rational without being scientific, flexible without being unbounded, judgmental without being arbitrary and predictable without being predetermined.

\section{Rude awakenings}

In the thirty years since the original publication of The Concept of Law, the focus of jurisprudential attention has become (trans)fixed on the adjudicative function; what was once merely a small part of the juristic project has become its almost total concern. While Hart's ideas are no longer thought to be entirely pertinent to the contemporary agenda of pressing issues, legal 
theorists have not so much rejected Hart's rule-based positivistic account of adjudication as tried to qualify it in various ways. Taking a leaf from the litigator's notebook, they have tried to both confess (rules are important in law) and avoid (rules are not exhaustive of law) the force of Hart's claims. Critics and defenders alike have retained Hartian positivism's central article of faith namely, that rules are the basic currency of legal transactions and that they have a core meaning that can deal with and resolve most situations. Even the most anti-positivistic jurist, like Dworkin, accepts that there are frequent occasions on which a rule 'applies itself ${ }^{30}$ and even the most pragmatic theorist, like Posner, embraces the idea that the skill to apply rules in a creative way and to make that application persuasive to others is the hallmark of the good lawyer and judge. ${ }^{31}$ However, the efforts to qualify and distinguish Hart have not been trivial. They can be grouped into two main trends a naturalist resurgence and a positivistic retrenchment.

The great majority of jurists has sought to envelop an understanding of law and adjudication in a larger and more expansive moral universe. Although Hart was accurate in observing that rules were open-textured and their application did not exhaust the judicial function, these neo-naturalist jurists argue that he failed to appreciate the extent to which the law consists of more than rules. Behind and within the rules is a political morality that guides and constrains judges when the application of rules was unclear or undesirable. Law was about values and politics, but not in any idiosyncratic or ideological way. The primary task of theorists and judges is to detect and cultivate the politico-moral principles that breathe life into the dry bones oflegal rules. For 
some, the legal process is a subtle economic game in which the invisible hand of the market shapes and wields legal rules in the best approximation of wealth maximisation; for others, legal doctrine is a morality play in which individual rights struggle with collective interests over the soul of constitutional justice; and for still others, the courts represent a privileged site for a continuing civic dialogue over the possibilities and parameters of democratic governance. ${ }^{32}$

A smaller group of jurisprudential scholars has maintained that Hart fudged on the moral basis of law. Agreeing that Hart's attempt at compromise was not a triumph, but a sell-out, they concluded that Hart was a radical in traditionalist's clothing who had reneged on the democratic compact by letting the political cat out of the legal bag. However, rather than salvage the legal enterprise by mixing in more morality, these arch-positivists seek to redeem the democratic legitimacy of law by purifying it of any moral entanglements. Such a hard variety of positivism treats law exclusively as a matter of social fact and not a moral ideal. ${ }^{33}$ While not everything judges say or do is law, their application of legal rules not only can but must be free of moralising; to do more (or less) would be improper, unjudicial and undemocratic. This is not so much an amoral stance as a moral position that defends a legalism of strictly rule-bound adjudication as the most morallydefensible account of law and adjudication in a constitutional democracy. It is a vision of judging that celebrates the systemic virtues of regularity, predictability and certainty over the concern with substantive justice in particular instances. In one of its most uncompromising incarnations, Justice Scalia insists that '[t]here are times when even a bad rule is better than no rule at all. ${ }^{134}$ 
In spite of their obvious differences, these conflicting naturalist and positivist trends are united in their shared and enduring formalistic belief that there must be a clear and defensible line between valid adjudication and ideological disputation. Both maintain that legal reasoning is a sufficiently detached and determinate enterprise that can generate correct and predictable answers to social disputes in a way that marks it off, in a non-trivial and meaningful way, from open-ended political wrangling. While immersed in politics and history, law is its own thing and not entirely reducible to anything else. Without such a possibility, the fear is that the Rule of Law will be subverted and democratic governance will succumb to the tyranny of special interest groups. Moreover, without adequate determinacy in legal discourse, judicial arbitrariness will become the order of the day and adjudication will collapse into a series of ad hoc and unprincipled encounters. Accordingly, positivists and naturalists agree that the preservation of the Rule of Law 'has the value of promising to make politics safe, of preventing Leviathan from becoming Frankenstein's monster ... [of imposing] real restraints on arbitrariness or despotic conduct. ${ }^{35}$

The important question for both the positivist and the naturalist account is not whether law in large part can be represented as the application of clear rules wrapped up in intelligible doctrine, but whether it ever can be so. It is my sceptical contention that it cannot. Supported by a postmodern reading of Hart, I resist the claim that there is an abiding core meaning to rules that can be located and relied upon in applying them. While there is always a topical 
distinction between the core of a rule's meaning and its penumbral uncertainty at any particular moment, this relation between core and penumbra is contingent and cannot provide the stability and fixity that its proponents suggest and require; yesterday's penumbra is today's core which will be tomorrow's penumbra. People bring different experiences to rules and, therefore, interpret and follow them differently: there is no uniformity of experience and, therefore, no uniform experience of what it is to follow a rule. Any claim that judges are only held back from a frenzy of arbitrariness by the restraining power of rules is not only unrealistic, but also does scant credit to the integrity and efforts of most judges.

In the process of explicating what a postmodern application of rules entails, I will defend my version of rule scepticism against the exaggerated claims of the third strain in contemporary jurisprudential criticism -the so-called nihilists. This disaffected small group has let their critical zeal overcome their intellectual insight. They have pursued an extreme line of hyper-sceptical argument which has exacerbated the formalist fear that, without some plausible account of determinate rule following, there will be an official anarchy .in which rules will count for nothing or simply be used as ex post rationalisations for ex ante decisions. For instance, Tushnet concedes too much when he states that if he were appointed to the bench he would adopt a 'currently fashionable theory' of adjudication and then use it to advance the cause of socialism or whatever. ${ }^{36}$ This fails to take the legal enterprise seriously and offers no real challenge to its theoretical legitimacy. After all, as Hart insists, the judges' experience of actually applying rules must be 
incorporated into and explained by any cogent account of adjudication. Moreover, a nihilistic perspective persists in the error that judges can step out of themselves and adopt some view from a legal nowhere. In contrast, I contend that the judges are both more and less constrained by rules than any of the positivists, naturalists and nihilists think. They are more constrained in the sense that they cannot land completely outside of rules and exercise an entirely free choice, but they are less constrained in the sense that they are not obliged to reach any particular decision as the result of a commitment to resolve disputes through rule application.

Contrary to a nihilist perspective, therefore, I maintain that nothing is lost to the radical critic (and everything is to be gained) by taking the legal enterprise seriously. Of course, this is provided that taking law and adjudication seriously means doing so in a postmodern way. It is not so much that rules do not exist, but that they do not exist as canonical directives whose meaning is available without interpretation and which can impersonally dispose of cases. The meaning of a rule and its application never simply is it is something to be argued for or with and not something to be argued from. As conventional and social matters, the meaning and application of rules is contextual and, therefore, open. The fear of rule-free choice is as contrived as faith in rule-bound choice.

In presenting a postmodern's Hart, therefore, I defend a modest and Hartianinspired position that is situated between the excesses of both a naturalist and a positivist approach on the one side, and a nihilist critique of law and adjudication on the other. In other words, I will articulate a critical 
account of lawyering and judging that takes rules seriously in the only way that they can be taken seriously as a special kind of activity or game which is defined by rules and roles, but in which the nature and effect of those rules and roles are themselves always in play. Such an account will consolidate the traditional rejection by positivism of the naturalists' pretension to project law as a seamless web of doctrinal filaments. As importantly, it will provide a much-needed corrective to any tendency to present rule application as nothing more than a transparent exercise in self-delusion. 37 In the process, I will explain how the concession that there is widespread predictability to the legal and judicial process is not fatal or even embarrassing to the sceptical claim that the body of legal rules is radically indeterminate. When properly understood, the sceptical claim is not that 'anything goes,' but that 'anything might go.'

\section{From ambiguity to indeterminacy}

Hart's masterstroke was to introduce the linguistic lessons of Wittgenstein and his Ordinary Language colleagues to the study of law. Indeed, Hart was one of the first lawyers to take seriously the idea that law was a linguistic practice and that the jurist's task was to clarify and elucidate the social use of legal statements and linguistic practices. Consequently, his general jurisprudence and particular account of judging is driven by and given much of its intellectual shape by his understanding of language's role. He thus shifted the focus of jurisprudential attention away from philosophical abstractions toward a more practical view of law-as-social-activity. In the Hartian canon, law was not a heavenly body but had feet of clay. However, in importing Wittgenstein's ideas tojurisprudence, Hart got 
more than be bargained for. Intended as mild correctives to a tendency in jurisprudence to abstraction, the notions of convention and context are a strong form of theoretical purgative. Although Hart strives to confine their effects, such debilitating ideas are fatal to many of the basic concepts upon which Hart builds his theory of law.

\section{A weak Hart}

Until the late nineteenth century, language had generally been taken for granted. Treated as a transparent medium through which, if used properly, the light of meaning shone, it had eluded sustained or searching critique. Philosophers tended to proceed as if words were incorporeal elements that existed in an abstract realm whose unique meaning had to be revealed and refined. However, the advent of the 'linguistic turn' in philosophy brought an end to such naivety. While this concern with language took many forms and directions, the most important for English jurisprudence and Hart's positivism was the so-called Ordinary Language School of Philosophy which drew its intellectual inspiration from the later writings of Wittgenstein. For Wittgenstein, many of philosophy's problems had been verbal and self-imposed because theorists insisted on taking words out of their context and separating them from their function: 'philosophical problems arise when language goes on holiday. ${ }^{38}$ Abandoning the idea that language had an enduring relation to the world and that words' meanings were simply pictures of that world, his major insight was that language was a human activity and that words served different needs in different ways at different times. Accordingly, meaning was to be understood through the word's function and the rules which 
governed its use.

By way of the work of J.L. Austin and Gilbert Ryle, ${ }^{39}$ Hart set out to introduce this bracing linguistic scepticism into the staid corner of juristic deliberation. In his inaugural Oxford lecture in 1953, he cast grave doubts on the adequacy and validity of attempts to supply a traditional definition per genus et differentiam of law and basic legal conceptions: it was not possible to provide a set of necessary and sufficient conditions for the use and meaning of a word. Instead, he emphasised that such words as 'law' and 'right' do not stand for any abstract entities or describe any pre-existing factual reality. ${ }^{4}$ For Hart, the relation between legal words and the world was neither straightforward nor mirror-like. The adequacy oflegal definitions is not to be found in their correctness, but in their usefulness to achieve the particular aim in question. As such, the point of The Concept of Law was 'to advance legal theory by providing an improved analysis of the distinctive structure of a municipal legal system and a better understanding of the resemblances and differences between law, coercion and morality, as types of social phenomena. ${ }^{41}$ Accordingly, Hart is anti-reductionist in that he views legal terms as irreducible to hon-legal language or some non-linguistic reality; Hartian jurisprudence is, therefore, touted to be as much about sociology as philosophy and as much about convention as universality.

Beginning from such a language-centred premise, Hart was persuaded that jurisprudence should consist of attempts to elucidate the underlying and recurrent themes of legal thinking through exposing the multitude of legal shadows and ambiguities in habitual legal usage. This approach did not do away 
with definitions entirely, but recommended a much less abstract and more contextual analysis of legal language: definitions were to be general approximations rather than final explanations and could not be used as incontrovertible postulates from which conclusive axioms could be logically inferred. Consequently, words like 'rule,' 'right' and 'legal person' could not be defined by pointing to corresponding things or actions in the external world, but could only be understood in terms of their legal function and social usage. Hart urged that certain ground rules could be drafted and observed in giving meaning to legal constructs: first, put them into the context of the whole sentence; next, specify the conditions under which the whole sentence is true; and then, show how that sentence is used in drawing a conclusion from the rules in a particular case.

Nevertheless, the social factness of law will confound efforts to construct a scientifically precise or purely abstract account of law. As a conventional linguistic practice, law shares the imprecision and messiness of social life. While there are better and worse ways to participate in and practice legal language, there is no perfectible use of legal language. Any attempt to fix the meaning of particular words will be defeated by people's 'relative ignorance of fact... [and] relative indeterminacy of aim. ${ }^{12}$ For Hart, people's inability to predict or anticipate the future with confidence ensures that the struggle to communicate in a clear and unambiguous manner is hubristic and, as such, is doomed to failure: 'uncertainty at the borderline is the price to be paid for the use of general classifying terms in any form of communication concerning matters of fact. ${ }^{143}$ Within the Hartian view of law, philosophical clarity is 
bought at the price of practical uncertainty, and social determinacy at the expense of theoretical legitimacy. However, while words must be understood in their linguistic context and lack any absolutely determinate meaning, Hart maintained that words do have a core of settled meaning; there are some standard instances which guide their use. Without this sense that a particular string of words 'fixes necessary conditions which anything must satisfy if it is to be within the scope and certain clear examples of what is certainly within its scope may be present to our minds, ${ }^{144}$ communication would not be possible. However, in Hart's view, outside their core of settled meaning or standard instances, general statements will have a penumbra of indeterminacy, a fuzzy border in which the bewildering interaction of wordly flux and human ingenuity will confound attempts to give words sharp and clear-cut edges. In such peripheral regions of uncertainty, general agreement in judgments about meaning will have to be reached actively rather than simply recognised:

the classifier must make a decision which is not dictated to him, for the facts and phenomena to which we fit our words and apply our rules are as it were dumb. Fact situations do not await us neatly labelled, creased and folded, nor is their legal classification written on them to be simply read off by the judge. Instead, in applying legal rules, someone must take the responsibility of deciding that words do or do not cover some case in hand with all the practical consequences involved in this decision. ${ }^{45}$

However innovative and different Hart's resort to the themes of Wittgensteinian linguistic analysis appeared in the 1950s and 1960s to the Anglo-American jurisprudential establishment, it was characteristically cautious and considereo. In his inaugural lecture itself and later in The Concept of Law, Hart hedged on the importance and implications of context 
and function for linguistic analysis: they were more like helpful accessories than fundamental tools for moving beyond a strictly 'representational' understanding of language. For instance, although he argued that legal terms are not used 'to stand for or describe anything,' they 'do not have the straightforward connection with counterparts in the world of facts which most ordinary words have and to which we appeal in our definition of ordinary words. ${ }^{16}$ Hart seems to think that the dependence of meaning on function and context is a pecularity of formal systems of language, such as law and games: law is an anomalous mode of expression. In view of this, he is fond of talking about the 'natural expression' of certain concepts and points of view as though their meaning was fixed and determinate across and among different contexts. ${ }^{47} \mathrm{He}$ fails to appreciate that the contextual and functional insight is as salient to the operation of the vast number of informal and overlapping practices that comprise language as a whole. Moreover, without such an acknowledgement, Hart's commitment to a truly functional and contextual understanding of language is seriously attenuated and fatally compromised. In so far as the content of Hart's use-based rules and rights draw upon and connect to 'ordinary language,' the resort to context and function is rendered marginal and insignificant.

This debilitating tendency is reinforced by Hart's indication of what it means to take a contextual approach to legal language. His treatment of sentences as the prime unit of meaning rather than as a series of isolated words was only a first step. Hart went no further in his embrace of a contextual analysis than to suggest that it was possible to attach meaning to legal 
constructs by putting them in their larger grammatical context and by recognising 'the cardinal principle that legal words can only be elucidated by considering the conditions under which statements in which they have their characteristic use are true. ${ }^{48}$ This is little more than a cursory nod in the direction of social usage; Hart remains indebted to a representational understanding of language. He most certainly does not escape the 'picture' theory of language, but only extends its range of brushes and palette of colours. In so restricting contextual analysis, Hart comes almost as close to talking about the truth conditions for linguistic application as those traditional linguistic theories from which Wittgenstein was at pains to distinguish his own work. ${ }^{49}$ Indeed, while Hart dresses his theory in the fashionable Wittgensteinian trappings of social context and conventional usage, it is in its essentials a traditional and objectifying body of ideas. Static, technical and ahistorical in its understanding of social convention, The Concept of Law lacks any appreciation of social life as dynamic and contingent.

For instance, Hart seems to believe that, at least as a metaphysical possibility, language is capable of being unambiguous, provided that sufficient information could be generated to overcome 'relative ignorance of fact ... [and] relative indeterminacy of aim. ${ }^{150}$ There would be a transparency between the words used to express speakers' intentions and the world described by those words such that hearers could not be confused or unsure in their understanding. In leaving open the possibility of such metaphysical perfectibility, Hart does not live up to the sceptical expectations that his Wittgenstein dalliance raises and encourages; The Concept of Law is a well- 
intended but unsuccessful attempt to contain the subversive implications of a thoroughly contextual and sceptical approach to law and language. Not only does Hart fudge important questions about the historical and political dynamism of language, he fails to understand that language is not only textually ambiguous but is structurally indeterminate. Because 'a context, always, remains open, thus fallible and insufficient, ${ }^{51}$ context cannot do the explanatory and justificatory work that Hart and others ask of it. As much as context enables the possibility of any meaning at all, it disables the possibility of a fixed or settled meaning.

Consequently, the next part of this section follows through on the sceptical process that Wittgenstein began (but did not finish) of unburdening language of its lingering metaphysical baggage and that Hart began (but did not finish) of flushing out law's epistemological pretensions. My critique begins, not ends, with the claim that meaning is ambiguous and multiple. From there, it goes on to make a much more challenging set of claims about language and, therefore, law's attachment to rule application. The thrust of an uncompromising sceptical critique is to ensure that rules are never the basis of agreements, but that agreements are always the basis of rules.

\section{A strong scepticism}

Central to the resort to linguistic analysis was the possibility that it might utilise language to plumb the epistemic depths of reality and necessity; Aristotelian 'things' and Kantian 'minds' had not proved equal to the task. The basic gamble was that philosophical problems could be resolved, or at 
least eased, by taking language and its everyday use more seriously. However, contrary to what Wittgenstein proclaimed, this endeavour only demonstrated that language was as likely to bewitch our intelligence as philosophy or anything else. ${ }^{52}$ There is no literal language one that is representational rather than constitutive against which other languages, such as law, can be contrasted. The study of language is not the last, best hope of philosophy, at least as traditionally understood, because it is itself shot through with all the contradictions and conundrums that philosophy strives to resolve: it is a case of out of the philosophical frying pan and into the linguistic microwave. If philosophy has any particular mission or ambition (and I doubt that it has), it is not to isolate Truth or confirm The Way Things Really Are, but to challenge old shibboleths and generate new and interesting truths that better serve humanity's efforts to improve itself.

An old philosophical gloss does much to prick the balloon of philosophical conceit and to highlight the way that language does (and does not) work: 'to do is to be' Sartre; 'to be is to do' Nietzsche; and 'do be do be do' Frank Sinatra. Both the point and the recitation of this gloss, illustrating that language is very much a practice unto itself, contradicts the claims and assumptions of many epistemologists. In particular, it highlights traditional philosophy's failure to grasp fully the implications of the critical idea that there might not be a transparency between the signifier and that to be signified -there may be all kinds of contextual forces in play that intervene. Discursive usage and practice are not the positivistic foundations that Hart and others claim them to be; they are riddled with political and 
social cracks. Language is not something that is a mirror or window to reality, but is always part of that reality: language is constitutive rather than designative. The relation of mind, language and things is not about causal necessity but about functional adequacy. This is as much a matter of prescriptive fit as descriptive accuracy.

Reality cannot be known outside of the discourse through which it is apprehended. In a post-Kuhnian world, there are no theory-independent facts or, what Wittgenstein termed, 'superlative fact(s) ${ }^{153}$ that comprise an unambiguous starting point for philosophical analysis; there is no object of inquiry outside a context of inquiry. This insight is doubly valid for language and law. There are no 'facts' about the way legal language works that are not themselves beholden to some theory about what counts as law, language and social facts. Of course, this is not to subscribe to the absurdly idealistic view that there is no world which functions outside of language and that reality is 'begot of nothing but vain fantasy/ Which is as thin of substance as the air/ And more inconstant than the wind. ${ }^{54} \mathrm{I}$ argue that, beyond immediate and personal sensations of the physical environment, the world is only accessible and knowable through language; life is an interpretive activity. While communicative practices are not the only kind of practices, they do frame and give meaning to other practices and are important for that reason. Consequently, Hart's insistence that the meaning of certain words, like 'vehicle,' is somehow a fact, that its definition simply is and its authority is self-evident, is not tenable: language and meaning are always hostage to their historical and theoretical context. 
Understanding language, therefore, is not about abstract reflection, but it is about social activity. The key relation is between speakers rather than between words and things: 'if language is to be a means of communication, there must be agreements not only in definitions, but also (queer as this may sound) in judgments' and, therefore, 'the speaking of language is part of an activity, or a form of life. ${ }^{55}$ For all his good intentions, Hart fails to follow through on this fundamental Wittgensteinian insight. He treats ordinary language as not only the first word, but also and this is the problem as the last word on its philosophical significance. Contrary to Hart's view, ambiguity in language is not the result of inadequate or imprecise attempts at definition, but is a result of the systemic and structural problem that, as meaning depends upon agreement, there is no sufficient or adequate common ground among users of the language as to what particular words mean in particular circumstances. The world of people and, therefore, of language is contingent; it never stands still long enough to reach social consensus or historical closure. This. view of language does not deny the possibility of meaning, but is fundamentally sceptical about the status and stability of any meaning reached. Thus, it is more easily understood that, while context manages to account for the operation and intelligibility of language, it simultaneously manages to undermine the possibility of grounding it in anything but context itself. ${ }^{56}$ While the judgments that stand behind and within language are not always reflected upon, legal cases provide an occasion when they can be. Indeed, unlike mathematics, law is an exercise in reflective activity.

While this sceptical approach to language rejects the notion of language as 
an exercise in representational precision, it does not obliterate or essentialise the distinction between discursive representation and reality, but renders it organically unstable and normatively volatile. This is only fitting because scepticism is sceptical about all things, including scepticism itself. But this does not mean that sceptics disbelieve everything: this is as absurd as suggesting that absolutists belive everything. Sceptics are sceptical about what to be sceptical about. They hold beliefs, but in a provisional and conditional way. Accordingly, to be sceptical is not to be relativistic; its notions of truths are pluralistic and, cutting across and within social cultures, are not reductive in epistemological provenance. ${ }^{57}$ Moreover, as Hart again recognised but did not fully grasp, it is not possible to develop a theory of meaning from such a pragmatic conception of language. The ascertainment of meaning is never reducible to some formulaic or fixed process of abstract reflection, but is always susceptible to the vicissitudes of flawed and incomplete social practices. A sceptical or deconstructive enquiry abandons entirely a transcendental attachment or ambition to fix foundational conditions for language. Instead, its task is to expose the dynamic fluidity of those foundations. It is appropriately non-foundational rather than dogmatically antifoundational.

Consequently, whereas language is constitutive rather than designative, contextual rather than abstract, and political rather than metaphysical, Hart's claims about the 'relative indeterminacy ${ }^{158}$ of law, in the sense of rules being vague, ambiguous and competing, are misplaced. Law and language is thoroughly and pervasively indeterminate. Whereas ambiguity suggests a 
textural property that is capable of final resolution, indeterminacy represents a discursive or linguistic property that pervades the whole interpretive act so that any final resolution or interpretation is unavailable. Structural indeterminacy gives rise to a hermeneutical undecidability in the sense that there can be no final closure to any claim for meaning. ${ }^{59}$ Different meanings are brought about by differences in context. There is no context of context in that there will always be disagreement about what the proper context of any law or rule is. Accordingly, it is the disagreement over context that creates the ineradicable presence of indeterminacy. Interpretation is not a matter of indisputable proofs that establish the term and conditions of legal language, but a series of rhetorical probes in a continuing conversation about and within legal discourse. This demands a refocusing of critical attention away from a Hartian preoccupation with epistemological concepts to a sceptical concern with social contexts.

\section{A vehicle for indeterminacy}

'Indeterminacy' is itself controversial even among those who subscribe to a sceptical view of law. My own understanding is not reducible to the claim that 'anything goes' at any time. It is most decidedly not a facile contention that judges or lawyers are free to do whatever they wish: it is a claim about the instability and undecidability of legal meanings as historical and political phenomena. I reject the possibility of any sovereign and unconstrained interpreter as I reject the possibility of any authoritative and constraining text. Accordingly, claims that 'the court has complete discretion to achieve any 
outcome at all' are fantastical and miss the whole point of a postmodern perspective. ${ }^{60}$ There is a difference between someone who is trying to make sense of a particular text and generating multiple and contradictory meanings and someone who is not making that effort at all and is self-consciously grafting a gratuitous meaning onto a particular text. ${ }^{61}$ Unlike the latter, the former involves a good faith account of legal interpretation in which the interpreter must hold a practical and actual belief that the law does permit such a course of action. If there is, the debate over meaning will be joined as one about substantive wisdom as opposed to interpretive correctness.

However, although insistence on the endemic instability of law does not dictate that meaning is always elusive, it does hold that meaning's continuous slippage and instability does prevent the establishment of any meaning that is fixed and beyond further interpretative contestation. While meaning is always parenthetical and can never be grounded, the possibility of meaningful dialogue is always available: it is the theoretical status of such practical meaning that is debatable. Interpretation is always constrained because, without constraints, interpretation would not be possible. However, the constraints are both always in place and never themselves outside of interpretation. There is no politically uncontroversial or historically independent way of determining that interpretation was correct or that the appropriate constraints are operative. As such, the indeterminacy thesis is itself indeterminate. Law is indeterminate not in relation to a stable social context, but because of the indeterminacy of that social context. It is a non-instrumental account of law because it resists the idea, shared by fundamentalist Marxist, feminist and Chicagoan theorists, that 
it is possible to map with any certainty the correlation between the forces that give rise to concrete interpretations of particular rules and doctrines and the interests that those interpretations serve. ${ }^{62}$ It must be emphasised that indeterminacy depends upon determinacy in that, in order to recognise indeterminacy, it is important that there is a contextual backdrop of determinacy against which indeterminacy can be identified. Accordingly, what is and what is not indeterminate will shift. In a manner of speaking, temporary and local determinacy is framed by lasting and general indeterminacy. Legal meaning is a simultaneous mix of the determinate and indeterminate. In Hartian terms, this translates into the acknowledgement that rules will be experienced as having a core of accepted meaning and a penumbra of uncertainty, but the identity of each will shift and change; what was once thought to be at the core will become penumbra) and vice versa. The relation between core and penumbra cannot be described once and for all: it is a sociohistorical artifact and cannot be reduced to a simple formula or overarching narrative. ${ }^{63}$ Whether particular interpretations of a rule are or are not compatible is not the point. It is the fact that the question of their compatibility is always open and contestable.

It takes little effort or imagination to illustrate this contingent and shifting relation between the core and penumbral meaning of 'vehicle.' For Hart, it is clear that 'if anything is a vehicle a motor car is one,' but it is equally unclear whether it includes 'bicycles, airplanes, roller skates. '64 Although, at any particular time in any particular place for any particular purpose for any particular community, this delineation of vehicle's core and penumbra may accurately track the prevailing 
consensus, it is difficult to sustain and defend this precise division as an enduring account of vehicle's meaning. Even within a particularised context, there will be debate and disagreement over not only whether penumbra! cases sufficiently resemble core instances to warrant inclusion as vehicles, but also where the line between core and penumbra is to be drawn does a motor car include a police car, ambulance or maintenance vehicle? Does it encompass a child's toy, a wheelchair, a child's stroller, a lawn mower or a statue of a motor car? ${ }^{65}$ Moreover, Hart's injunction to consider words in their grammatical context is as likely to result in further confusion as improved clarification -does 'park' include an industrial estate as well as a recreational enclosure? Does it include a car park? An extended historical example underlines the extent to which the core and penumbra of words, like 'vehicle, ' shift and reconfigure in the effort to apply the rule 'no vehicle may be taken into the park.' In the early part of the eighteenth century (or before), the core and penumbra of vehicle clearly did not include motor cars; they were not yet invented. It was animals and animal-drawn conveyances, like wagons and sleds, that dominated the vehicular scene. For instance, in 1868, pre-car London introduced traffic controls and pedestrian crossing signals. The police notice warned that a manually-operated semaphore would indicate Stop or Caution to 'all persons in charge of vehicles and horses. ${ }^{166}$ Indeed, as late as 1925 in Washington, it was unclear whether the power 'to regulate vehicles on public streets' encompassed automobiles as they were unknown as a practical means of conveyance at the time of the regulation's original enactment in $1887 .{ }^{67}$ Ironically, by 1922 in Alabama, an animal unattached to a conveyance had been held not to be a vehicle for the purposes of a statute authorising the confiscation of 
vehicles used for criminal activities and, by 1925 in Virginia, animal-drawn conveyances were not considered to be included within the ambit of vehicles. ${ }^{68}$ Projecting forward a few decades into the next century, it is not inconceivable that the motor car will have had its social day and have moved back into the penumbra! regions of linguistic usage: it might be replaced by an environmentally-friendly return to animals and animal-drawn carriages or by some futuristic means of transport that has only presently begun to register faintly on the present social consciousness.

The point of this example is not to demonstrate that 'anything goes,' but that 'anything might go.' While meaning is always available, it is never socially stable or historically fixed; historical contingency confounds linguistic certainty. The settled possibility of establishing meaning at any particular time is always haunted by the impossibility of settling on established meaning for all time. My sceptical account urges, therefore, that it is entirely plausible to believe in indeterminacy and, at the same time, still have confidence in particular interpretations of particular rules at particular times in particular circumstances, provided that such confidence is based upon rhetorical cogency and not epistemological truth value. In Hartian terms, the attempt to define 'vehicle' is not only periodically hampered by the word or rule's textual ambiguity, but is permanently incapacitated by language's structural indeterminacy.

In such matters it is important that the question of law's indeterminacy is not confused with its predictability. For instance, Greenawalt proposes, as a justification for his claim that the law has a workable level of determinacy, that 'virtually any lawyer ... would conclude, after careful 
study, that the law provides [a particular] answer. ${ }^{169}$ Even this modest and pragmatic standard is problematic and self-serving; it mistakes predictability for determinacy. If 'virtually any lawyer' includes those lawyers of a critical or deconstructive disposition, it will be extremely difficult to ever 'conclude, after careful study, that the law provides [any determinate] answer.' If such lawyers are not included, determinacy will have been achieved by hypothetically polling only those lawyers that already believe that determinacy is possible. Intended as a non-controversial and itself neutral standard of determinacy, Greenawalt' s proposal falls afoul the indeterminacy critique: it confirms rather than refutes the contingent and inescapable politics of law. Meaning and determinacy are not properties of the law itself but a function of agreement among lawyers about its relevant informing contexts. Indeed, as the example of a professional legal community confirms, many of the judgments and much of the agreement that Wittgenstein argues makes language work is brought about 'through training, drill and the forms of our life. ${ }^{70}$ To be a lawyer is to talk like a lawyer and to talk like a lawyer is as much about the inculcation of social values and attitudes as it is about the learning of legal rules and technical words.

\section{Hart and soul}

In 1978, MacCormick felt confident enough to state that 'no one has ever advanced' an assault upon easy cases. ${ }^{71}$ By this he meant that there existed cases in which the application of the rules to the facts was beyond reasonable 
dispute; the jurisprudential action was more around the incidence, identity and resolution of hard cases. However, the sceptical account of law launches just such a full-frontal assault. It challenges the distinction between hard and easy cases and contends that all cases are vulnerable to sceptical disruption. Indeed, an uncompromising scepticism is devastating to traditional jurists' intellectual peace of mind because it not only disputes the naturalist claims made for the adjudication of hard cases, but also strikes at the hard core of the positivist thesis. In no uncertain terms, a sceptical account of law insists that there never is simply an easy fact of the legal matter; it is indeterminacy all the way down. The sceptical life of the law is both the indeterminate logic of its own contingent experience and the indeterminate experience of its own contingent logic.

\section{The hard core}

For Hartian positivists, the existence of easy cases is essential for a positivist analysis and as ajustification of its jurisprudential raison d'etre. This commitment flows from their basic thesis that law is a matter of social fact and that there is a conceptual separation between those facts and the law as it ought to be. If there were not easy cases, and a considerable number of them, law could not be considered as a social fact independent of moral considerations; it would be entirely a matter of judgment and an occasion for the exercise of strong discretion. While Hart does not claim that rule application is logical, he does argue that there are 'a vast number' of determinate rules whose application will be obvious and unproblematic in the bulk of cases. ${ }^{72}$ Although absolute 
certainty is not an achievable goal and 'a margin of uncertainty should be tolerated and indeed welcomed,' Hart concedes that, for the positivist claim to hold true, there must be an operational degree of certainty or else 'there is no central element of actual law to be seen in the core of settled meaning which rules have. $m$ While Hart is right to point out the experience that lawyers and judges have of 'the core of settled meaning,' he is mistaken to treat 'the core of settled meaning' as a feature 'that rules have' and to consider that core or meaning as 'settled' in anything but the most temporary, provisional or contingent way. 'The core of settled meaning' is only central, settled and meaningful until the next roll of the hermeneutical or litigational dice.

As Hart so compellingly shows, the formulation and application of rules is fraught with uncertainty and difficulty. In his three-step process of inductive, deductive and discretionary decision, judges have plenty of institutional room to manoeuvre. ${ }^{74}$ However, once it is recognised that this takes place within the structural and endemic indeterminacy of discursive practice, a depiction of rulebased adjudication as factual and easy is far wide of the scholarly mark. The appeal of rules is also their greatest weakness. By trying to generalise inductively from particular circumstances and then later to particularise deductively from general statements, rule-based theories of law overlook the main sceptical insight that judging is 'all in the details' and that those details are constantly being reconfigured. Rules arise from and speak to social relations that are always subject to change and only have any particular meaning as a result of their consideration within a specific politico-historical context. Moreover, that context is never selfevident but demands an act of delineation 
that implicates values and power: 'the question can be raised not whether a politics is implied (it always is), but which politics is implied in ... a practice of contextualisation. ${ }^{175}$

As a matter of professional training and social custom, rule application does not lend itself to a definitive account of what it is to follow a rule. To declare that someone has followed or obeyed a rule correctly is to say little more than they did something the same 'as we do it. 7 The question is not whether there are rules or whether they are relied upon they clearly are. However, they do not exist as canonical directives that can impersonally dispose of cases without interpretive intervention; the meaning of a rule and its application never simply is. Rules determine nothing except customary reactions and dominant practices. As a social practice, rule application is not an analytical issue of formal realisability or causal necessity; conformity with is not the same as caused by. This agnosticism is what distinguishes the sceptic from the positivists and the nihilists. Simply providing the next number in a series is not the same as justifying this manoeuvre as a necessary following of a particular rule. In the same way that Newton's Law of Gravity did not cause or account for the apple falling, rules do not cause anything to happen. In matters of social behaviour, the most that a rule can do is to help understand whether the participants in such behaviour believe that they are following such a rule. As Wittgenstein concluded in justifying behaviour, 'the rule is ... what is explained, not what does the explaining. ${ }^{177}$ Rules are rough-and-ready indicators or markers of earlier values that other judges have been persuaded had sufficient agreement within or appeal to the relevant 
discursive community. In a non-trivial sense, therefore, every application of a rule is a remaking of the rule. Rule application is an occasion on which judges acknowledge, consciously or unconsciously, the values that hold certain social practices in place. As such, adjudication, no less than lawyering, is through and through about values, not facts, and about persuasion, not demonstration. Applying rules is a political matter of taking sides: the only questions are which and when.

As regards the traditional distinction between easy and hard cases, it should by now be clear that a sceptical account of law has no truck with it or need for it. In short, there are no hard cases or easy cases: there are only cases. 'Easiness' is not a property or quality that inheres within a case or rule. Rules and their application do not arise or make sense outside of an interpretive context. The easiness or hardness of cases derives from background facts about agreements in judgments, historical contexts and social stability. What goes on in easy cases is the same as in hard cases, only that its context is less contested and more taken for granted. In this sense, Hart is correct when he states that easy cases occur where 'there is general agreement that they fall within the scope of a rule, ${ }^{178}$ provided that the emphasis is firmly on the fact of 'general agreement' and not, as Hart seems to put it, on 'the scope of the rule.' The fact of this 'general agreement' (whether a matter of social consensus or social hierarchy) is important the greater its extent and strength, the greater the existential experience of easy cases and legal certainty. ${ }^{79}$ Nevertheless, no matter how extensive or deep the agreement is, it does not alter the fact that easiness can never become an 
intrinsic feature of the rule itself. The temptation to mistake dominant ways of thinking for natural necessity must be studiously resisted; the process is so ingrained and uncontroversial as to appear as if the process did not occur. My claim, therefore, that many cases are easy and that, as Hart says, 'general terms would be useless to us as a medium of communication unless there were such familiar, generally unchallenged cases' ( $p$ 123) requires that 'unchallenged' be understood in the postmodern sense as unchallenged in the present social circumstances. After all, easy cases are as much a product of hermeneutical interpretation as hard cases; they are not an occasion to forego the necessity for such interpretation.

There are two strands of critical response to the sceptical account of easy cases and what it means to take rules seriously the 'weird and bizarre' and the 'obvious and trite.' The first claims that there are some factual applications of rules that are so far-fetched and ludicrous as to be clearly outside the sope of the rule and cannot ever reasonably count as potential interpretations of the rule. For instance, Greenawalt observes that 'no plausible formulation of the statutory crime of theft, under present social conditions, will include the ordinary act of scratching one's nose. ${ }^{180}$ But examples like this seem to miss the whole point of the sceptical account. It is not the rule or its formulation that is determinative, but the social context and what is considered relevant in it that is significant. The constraints are more on people's imagination who but a Da Vinci could have imagined cars, computers or spaceships in centuries of old? than on the interpretive possibilities imposed by a rule's linguistic expression. In any 
circumstances in which the 'bizarre' or 'weird' situation would actually arise, the reasonableness of the interpretation would be much less implausible and much more contestable. ${ }^{81}$ Greenawalt himself underscores this by qualifying his observation as only being itself plausible 'under present social conditions.' In other words, the resort to outrageous examples actually underlines the force and extent of the indeterminacy critique if, in matters of theft, everything else goes, other than acts like scratching one's nose, then the extent of determinate and plausible meaning is so great as to offer no practicable constraints on rule application at all.

The second response insists that there are some circumstances that are so obvious and trite that, even under present social conditions, their status as easy cases cannot seriously be challenged in that the appropriate outcome of applying a rule is beyond serious dispute. For instance, when contemplating Hart's rule that 'no vehicles may be taken into the park,' even a critical Fuller agrees that there is 'no need to worry about the difference between Fords and Cadillacs. ${ }^{182}$ Such a bold pronouncement is premature. While it may well be that, in most situations and for most people, the make of car will not be relevant, it does not follow that it will be so in all possible situations. Again, it is the determination of context that is vital, not the rule's formulation. There are a number of circumstances in which the make of car might be treated as significant in the application of the rule. At a Ford factory or recreational facility, 'vehicles' might have come to be interpreted as prohibiting only those cars that are not made by Ford, such as Cadillacs; the obvious rationale being that there is an important difference between cars made by the park's owner 
and anyone else and that Ford wants to encourage its employees to drive only its own cars. After all, any scheme of discourse, of which law is the example par excellence, that could once refuse to count women as persons and later make women into men, seems a strange arena of human communication to insist and rely upon the determinacy, relative or otherwise, of language. ${ }^{83}$

Accordingly, both criticisms serve to confirm that which they claim to condemn the difference between the resolution of easy and hard cases is not one of intrinsic identity or separate processes, but one of relative obviousness based on situated assessments of relevant social contexts and agreements. Although my sceptical account stresses imagination over technique and persuasion over demonstration, it does not commit me to the untenable or nihilistic position that it will always be possible to make the application of a rule come out in the way that the judge wants it to. Sometimes, cars are vehicles and horses are not. But this is a matter of rhetorical achievement, not objective truth or ahistorical determinacy. In such circumstances, it does not mean that the sceptical account has failed to give a cogent or realistic account of law and judging. On the contrary, the very fact that scepticism accepts the existential experience of rule-boundedness is what makes it cogent and realistic. Without some explanation or place for that fact, a postmodern view of law would be sadly deficient in terms of its own commitment to situated and engaged forms of understanding and evaluation. Moreover, as almost all theorists and lawyers will agree, because a case cannot be brought within a rule, it does not follow that the case must fail. Even under arch-formalist accounts of law, judges can either 
fashion an exception to a rule or amend the rule. As Hart states, 'a rule that ends with the word "unless ..." is still a rule. ${ }^{84}$

\section{Sceptical judging}

Despite their differences, what unites traditional jurists of a naturalist or positivist persuasion is their fear that, without a plausible theory and realisable practice of bounded rule application, law will become indistinguishable from open-ended political wrangling; adjudication will degenerate into a series of ad hoc encounters in which justice will 'be left to the unguided, even if experienced, sage sitting under the spreading oak tree.' 85 However, like most spectres, the threat of nihilistic hordes waiting to ransack the juridical citadel of principled decision-making is as much as anything else the figment of a fevered jurisprudential imagination ${ }^{33}$ : it says more about the insecurities of the legal establishment than it does about the aspirations of the juristic rebels. Accordingly in this section, I will draw together the various fragments on what it means to take rules sceptically, and present a more sustained account of what a sceptical approach to judging does and does not entail. In particular, I will address the neglected issue of what the qualities of a good sceptical judge might be.

The possibility of sceptical judging is lampooned as, at best, oxymoronic and as, at worst, simply moronic. It is suggested that a sceptical approach to rules denies the existence of rules and therefore undercuts the possibility of anything that might reasonably be recognised as judging; all is mere pretence and decision-making is an indulgent will-to-power. For example, in an 
otherwise sophisticated and restrained monograph, Waluchow accuses critical legal scholars generally of adopting a rule scepticism:

according to which there are in actual fact no binding rules at all and judges simply decide cases on grounds of their own choosing. These grounds might be political, moral or personal. Judges only pretend to be following rules when what they are in fact doing is rationalising their blatant, and often abusive and reactionary, exercise of political power. ${ }^{86}$

This is the stuff of rank caricature. Although nihilist critics in their more polemical moments might have given unfortunate credibility to such assessments, this dystopian vision of sceptical judging is neither warranted nor inevitable. While some judges and academics might well engage in the occasional cynical manipulation of rules and ought to be held to account for such intellectual or political ingenuity, it is far from radical scepticism's claim that rules cannot or ought not to be taken seriously; what more often occurs is the good faith attempt to interpret and apply a rule so as to produce a satisfactory result. Judges do follow and apply rules, but what is the relevant rule and what it means to follow or apply it is always up for grabs. Consequently, for postmodernists, law remains primarily a system of rules, provided that its existence and operation is understood in a radically sceptical sense.

The common allegation that under a sceptical account 'rules serve not as sources of ex ante guidance, but as vehicles of ex post legitimation of decisions reached without regard for the rules,' is mistaken. ${ }^{87}$ The sceptical claim actually made is that judges do not stand outside the rules but inhabit the rules in a particular way. They are always situated within a context of freedom and constraint -never fully constrained nor ever entirely free. Judges 
give meaning to rules and their own lives in the constant struggle to negotiate the forces of freedom and constraint that constitute the rules and their own lives; they are freely constrained and constrainedly free. Indeed, freedom and constraint can only be made sense of reciprocally. The rule-engaged judge is neither context-dependent nor contexttranscendent; the rules and the rule user are enmeshed in a mutually affecting relationship. ${ }^{88}$ Thus, a sceptical account of adjudication takes seriously both the restrictive pull of rules and the liberating push of interpretation. One can neither dispense with rules nor with interpretation; each is what makes the other tick. Within a postmodern version of law there is not only no set of rules that stands apart from interpretive attempts at hermeneutical appropriation, but there is no literal interpretation one that claims to be transparently representational rather than opaquely constitutive against which other interpretations can be contrasted. Similarly, a postmodern approach is suitably sceptical about the traditional insistence that whenever judges attend to the consequences of applying a rule they are no longer applying the rule in any serious sense. It is willingly acknowledged that, whatever else they might be doing, judges are not engaged in rule application when they deliberately use rules as ex post justifications for decisions. However, sceptics argue that some resort to consequences is an unavoidably practical feature of rule application if 'resort to consequences' is used by traditionalists to refer to certain aspects of the rules' informing context. Without reference to something beyond the verbal formulation of the rule itself, it is nonsensical to talk about rule application. As I have been at pains to 
demonstrate, rule application only makes sense as a dynamic exercise in normative judgment, not as a passive act of unreflective conformity. Consequently, sceptics are only troubled when judges attend to consequences and nothing else; that is, when they forego or ignore their own good faith attempts at interpretation of the rules. The fact that judges arrive at different or even contradictory applications of particular rules is less of a concern than the failure of judges to take the rules seriously. While judges are obligated to apply rules, they are not obliged to reach certain decisions. Of course, to concede that there may be several applications of a rule that count as valid or legitimate is to confirm that law is rife with indeterminacy and that judging is riven with choices. As such, traditional jurists need not so much fear that anything goes as a matter of judicial decision that judges might decide cases on the basis of a coin toss, the litigant's hair colour, astrological charts or the like -but that, as a matter of rule application and through a process of rational disagreement, judges might justify almost any outcome. Again, a sceptical practice does not reduce itself to brute preference nor dispense with the possibility of rational debate. Scepticism simply insists that the idea of rational debate be understood and practised in a suitably sceptical way.

As Hart stresses, any credible description of rule application must be able to account for the beliefs of participants as to what they are doing or think they are doing. While legal theorists need not share or endorse the beliefs of participants in the legal community, they must offer an explanation of that behaviour as it is understood by its participants. Consequently, the fact that 
judges experience themselves applying and being morally bound by rules is a vital factor that cannot be ignored, even if it need not be endorsed or shared: 'description may still be description, even when what is described is an evaluation. ${ }^{189}$ Nothing that I have said contravenes this injunction. My sceptical account of what it is to take rules seriously accepts that a rule's existence will be relevant to the question of what judges do and should do. However, the need to incorporate judges' feeling of bindingness leaves open the key issue of how to fix what it is that that bindingness applies to namely, the rule's meaning. Notwithstanding Hart's emphasis on the beliefs of insiders, he posits a false tension between those who 'accept and voluntarily co-operate in maintaining the rules' and those who 'reject the rules and attend to them only ... as a possible sign of punishment. ${ }^{190}$ In so far as this division is intended to undercut the sceptics' claims about rules, it only bites if there is some largely objective, determinate and uncontroversial way to ascertain the meaning of rules. Because there is no such method, it is a toothless distinction. As I have tried to show throughout, the sceptical judge both 'accepts' rather than 'rejects' the rules and, at the same time, 'maintains' them as only 'a possible sign of punishment. '

Despite the apocalpytic predictions and dire warnings of traditional scholars, there is nothing about my approach that will necessarily change how judges actually apply rules. A different appreciation of what it is to apply a rule has no necessary impact on the practice of rule application: theory does not alter practice in and of itself. Judges and lawyers will still go on interpreting particular rules in particular ways. But what might change is the 
cogency and bindingness of particular applications in particular circumstances in light of the altered theoretical understanding of what it means to apply a rule: 'once we admit the rules are mutable and inextricable from material social practice, we will at least experience a psychological change in the way we perceive our roles as legal actors. ${ }^{191}$ There will still be general agreement on what particular rules mean and individual judges will still experience exactly the same degree of (in)determinacy, but the vital justification for that result will be subverted and the question of authority will be challenged. Judges will no longer be able to claim that 'the rule made me do it,' but will have to take greater responsibility for judicial decisions and their social consequences. Ifjudges believe that they should follow rules for the simple reason that they are rules, they will be lost when the rules are ambiguous or run out.

Democratic responsibility is not about unthinking obeisance to external rules; the denial of complexity and ambiguity in the service of the Rule of Law is the epitome of irresponsible behaviour. Instead, sceptical judges understand that their institutional duty is best fulfilled by taking stands on particular rules and being accountable for those choices. Indeed, Hart himself accepted that scepticism had two major and beneficial effects for the adjudicative enterprise -the practical and the political:

first, that [judges] should always suspect, although not always in the end reject, any claim that existing legal rules or precedents were constraints strong and complete enough to determine what a court's decision should be without other extra-legal considerations; secondly, that judges should not seek to bootleg silently into the law their own conceptions of the law's aims or justice or social policy or other extra-legal elements required for decision, but should openly identify and discuss them..$^{92}$ 
In prescient fashion, Hart was hinting, even if he did not concede, that the battery of adjudicative techniques for rule application did not amount to a selfcontained technology: they only made sense as part of a larger understanding of law as a rhetorical enterprise. Always a part of and not apart from power, law is a discourse of persuasion. Within such an understanding, non-apologetic legal theory demands a vigorous hermeneutics of scepticism that can penetrate the heavy jurisprudential camouflage in which power habitually disguises its insidious legal operation. While these competing strategies of adjudication are passed off as ideologically unaligned, they are rhetorical resources in a continuing struggle for the hermeneutical soul of law; their impact and success will vary with context and audience. Any meaning that gels is a rhetorical function of a temporary and provisional agreement between contending parties, not a lasting or concluding recognition of a pre-existing ground for interpretive truth. However, there is nothing arbitrary or capricious about this process; values, convictions and interpretations are no less real or compelling because they are contingent and historical. And they are no more real or compelling because they are underwritten by the spurious logic of some pseudo-neutral interpretive strategy. As Fish puts it, '[not] all rhetorical constructions are equal, just that they are equally rhetorical. ${ }^{93}$ In the sceptical almanac, the logic of the law is the rhetorical experience of life.

\section{A new craft}

What would be the qualities of good sceptical judges? What kind of people would make the best sceptical judges? While they would possess adequate 
technical skills, like a sophisticated grasp of rule application, these notoriously formal and abstract talents would not be central to a transformed practice of adjudication. Under sceptical tutelage, law becomes a practical activity in which judges would bear more resemblance to artists than technicians. Lawyers' highest achievement is not a reduction of law's materials to an elaborate and exhaustive system of rules; the effect, if not the intent, of a limited depiction of lawyers' special and distinctive expertise is that it too easily functions as a ruse for relieving themselves of the democratic responsibility to justify their power and authority by recourse to the real-world pressure of getting the job done. However, the best legal craftspersons are not those who simply reproduce mechanically and mindlessly old arguments and trite analogies, but those who can rework legal materials in an imaginative and stylish way. ${ }^{94}$ To be worthy of their professional prestige, lawyers and judges must nurture a sense of social justice and a feel for political vision unless they are to become only hired hands for vested interests: 'technique without ideals is a menace; ideals without technique are a mess. ${ }^{195} \mathrm{~A}$ bare legal craft can too easily acquire the elite habits of a masonic order and fail to meet the civic specifications of its official calling: a job well done is not always its own reward. Lawyers must be technicians, but they must also be designers and innovators who place their practised craft in the service of the disadvantaged and disenfranchised in society. As things presently stand, legal craft seems designed to serve only its own parochial and formalist ends.

The informing image of postmodern lawyers and judges is of industrial artists. Working with whatever materials are at hand, they mix and match 
them in an imaginative way that is a contingent expression of their artistic convictions about truth, beauty, justice, etc in a modern society. Unhindered by debates about the true nature of art or the correctness of artistic insight, the excellence of their craft is in their connectedness with the world, not some arcane retreat from it. Industrial artists are industrial precisely because they do not live exclusively in the studio, deal exclusively with paints and canvas, and speak exclusively to dealers and critics. Indeed, they are industrial in part because their contribution so often disappears into the product, blended with the contribution of other artists. But it is also bent to the discipline of technology, market constraints, popular tastes, union rules and other forces which marginalise them and their artistic aspirations and talents. The effect of this, over time, is to habituate them to their role in industry and to cause them to distance themselves from the effete world of Art. But, at the same time, they are changing industry by the improvements that they are able to make in the practicality, aesthetics and cost-efficiency of kettles and cars. For lawyers or artists the best accolades are earned not for their technical prowess but their capacity to engender local hope in the struggle to transform experience, to overcome suffering and to endow others with opportunities to remake their own world. ${ }^{96}$

To accomplish such a task, emphasis will be placed on the substantive qualities that judges possess as individuals and citizens. It is people who have a diversity of experience, who can open themselves to the situations of others and who value the worth of compassion, sensitivity and humanity. While it will not disqualify the hard-headed or the unsentimental, such a revised judicial 
mandate will require the capacity to be creative and imaginative in the use of rules. In so doing, such judges will not be acting in an arbitrary, idiosyncratic or ideological way. By working to bring their values and commitments to articulate consciousness in order to understand and interrogate them, they will be acting with the candour that democracy expects and taking responsibility for what they do in a way democracy encourages. By rejecting the hackneyed and unsustainable notion of an entirely differentiated role, judges might begin to gain the respect of the public and themselves. In the same way that 'good oratory is a good person speaking well, ${ }^{197}$ so good judging is a good person acting well. Of course, the notion of what qualities or characteristics go to make up the 'good person' is itself always open to debate and disagreement. Similarly, there is no magical guide to be followed as to what judges should do or how they should do it in any specific or conflicted situation. Sceptical judges will not shy away from a resort to values and will ensure that those values are always kept in play, that they remain open to reconsideration and that responsibility is taken for them.

Accordingly, by celebrating the fact that law is the continuation of politics by other rhetorical means, sceptical judges will recognise their inevitable role as agents of political activism. Rather than talk with Dworkin and Fuller about the common law 'working itself pure,' sceptical judges will be content to know that, through their own efforts and imagination, the law is simply 'working itself. ${ }^{198}$ However, none of this should be taken as implying that, when released from its allegiance to traditional prescriptions, judicial caution should be thrown to the wind and the courts begin to operate as a clearing house for 
all political disputes and policy-making. As formalists rightly note, 'giving away the traditional store ... would be drastic and dangerous ... unlikely to help the less powerful members of society. ${ }^{199}$ The postmodern challenge is to transform the courts so that they abandon their formalist ways and accept their political responsibility; it is not a ploy to usurp democratic authority from citizens at large.

Along with any efforts to re-vision the judicial craft in line with a more sceptical and democratic optic, it will be essential to ensure that the sites for democratic dialogue are actively multiplied so that a broader range of voices could be heard in society's policy-making. There is only so much that courts can or should do in a society that is committed to democratic governance. Nonetheless, in so far as courts are likely to play some role in the practice and theory of democratic justice, it will be imperative to work toward a situation in which the personnel of the courts are diversified and democratised. On the basis that different people bring different experience to the task of applying rules, the need to ensure that the elite ranks of the judicial and legal profession are opened up along more varied class, gender, racial, ethnic, sexual and political lines is paramount. Of course, the appointment of women, black or gay judges will not guarantee change or make the law more progressive. It is mistaken to believe that anything necessarily follows from the identity or experience of a judge: it is as wrong to attribute a homogeneity of views to disadvantaged groups as it is to pretend that those views will not be different to those of advantaged groups. Nonetheless, the increased presence of such people will increase the likelihood that a different perspective 
and vision of justice will be brought to bear upon the adjudicative process. While there are not nor can there be any metaphysical certainties, the institutional chances of transforming law and judging are greatly improved by opening it up to those excluded for so long: robust dialogue is more conducive to the democratic temperament and civic advancement than insulated monologues. This affirmative vision of sceptical judging 'is not radical in itself but is radical in the context of the prevailing orthodoxy.' 100

Similarly, within a postmodern legal culture, the role and representation of the jury would be greatly expanded. As an occasion for democratic devolution, jury empowerment would bring a neglected challenge to the aristocratic instincts of legal professionalism and might invigorate the timbre and range of dialogic debates. Moreover, it would represent a postmodern putsch against the legal hierocracy. By changing the civic members of the jury from passive observers to active participants, the legal process might begin to fulfil its democratic commitments. After all, law involves the lives of society's citizens and is much too important to be left to lawyers. Moreover, by withdrawing the fate of the polity from the clutches of lawyers, it might become possible for citizens to overcome the dispiriting belief that, unless there is something large, powerful and ahistorical on their side to support their claims -like the law -they need not assert their right to govern themselves. ${ }^{101}$ A revitalised jury system is one way to relieve the symptoms of democratic ennui and to prevent further political disempowerment. 


\section{Shovelling smoke}

If, as Oliver Wendell Holmes said, 'lawyers spend a great deal of time shovelling smoke,' 102 then legal theorists devote an even greater deal of time to producing it. Under the guise of elucidation, too much jurisprudential writing tends to mystify law and adjudication. On the other hand, a sceptical account works as a gust of fresh air to blow away much of the juristic fog that shrouds the doings of judges; it seeks to lay bare, not do away with, the creative craft of rule application. As part of a larger postmodern project, the ambition is not so much to dispel the uncertainty and complexity that is inherent in the adjudicative task, but to understand it better and encourage judges and critics to turn it to transformative effect. With a healthy sceptical attitude, judges might immunise themselves from the formalist contagion that both positivists and naturalists continue to spread. In this way, not only will lawyers begin to appreciate that they are engaged in a language game of rhetorical politics, they might accept that adjudication and rule application is not an escape from political responsibility but one of the most compelling occasions for its dutiful antl satisfying discharge.

In substantiating a sceptical account of law and rules, I hope to have calmed implicit Hartian fears that, without the hard core of settled meaning, there cannot be law 'in some centrally important sense' and 'the notion of rules controlling courts' decisions is senseless'; this is an unwarranted indictment of responsible scepticism and participatory democracy. ${ }^{103}$ It is simply not the case that, unless words have a context-transcendent meaning, the possibility of governance according to law will have vanished and anarchy 
will be loosed on an unsuspecting populace. While there is never a hard core of settled meaning, there is often a soft centre of temporary meaning. There are, no doubt, instances of cynical rule manipulation by judges and lawyers, but there is nothing in my postmodern refocusing of rule-based adjudication that denies or compromises Hart's observation that 'for the most part decisions ... are reached ... by genuine effort to conform to rules consciously taken as guiding standards of decision. '104 However, my sceptical approach does insist that nothing necessarily follows from making a 'genuine effort to conform to rules consciously taken as guiding standards of decision.' Moreover, the idea and practice of sceptical judging is best suited to the political ambitions of a modern polity that aspires to be truly democratic.

For Hart, the realists' tendency to treat rules as 'playthings' ${ }^{105}$ was to be strenuously resisted. When characterised in a nihilistic and trivialising vein, this reaction is understandable. But when the 'play' of rule application is understood in the more serious sceptical sense, it becomes much less disturbing and much more attractive. It begins to capture the style and substance of a postmodern politics in which citizens, including judges, are empowered by the recognition that rules are always up for grabs and that struggles to apply them partake of life's fluidity. Of course, such a view of politics as 'playful impertinence' might be seen to be indulgent and offensive to those whose lives are lived under economic and social oppression. To this objection there is no better response than that the practice of 'politics as play' offers the most seripus and pertinent challenge to such suffering. Under the 
view of law and life as an infinite game, play ceases to be only a pastime and relief from the grinding earnstness of life and rule application. Instead, it becomes an activity of living that is intended to permeate all situations of social interaction and that strives to 'open[ ] political spaces for agonistic relations of adversarial respect. '106 Within these patches of instability, conflicts of power might be challenged and robbed of their absolute and final predetermination in a way that ordinary politics and finite games do not. None of this suggests that there would be an anarchic lack of standards; there would be new and changing standards that combine the playful and the serious in a defiantly pluralistic amalgam of style and substance.

Within this sceptical understanding of law and politics, political players are capable of imagining and opening themselves up to possibilities other than those presently available. They are not actors in another's story, but they are committed to be 'joyful poets of the story that continues to originate what they cannot finish.' ${ }^{107}$ In such a postmodern society, politics is not something that people choose to do, but something that people always live. Consequently, when involved in the play of rule application, judges and jurists can continue to produce and shovel smoke or they can come clean on their political affiliations in a more open and responsible way. By taking rules sceptically and by diversifying the judicial ranks, the courts can become one more venue for the infinite game of democratic transformation. Moreover, in doing this it might be possible to confound and remedy Hart's complaint that 'in law, as elsewhere, we can know and yet not understand.' ${ }^{108}$ Suitably read and re-viewed, The Concept of Law still has a major role to play in that progressive challenge. 


\section{Notes}

1. Hart, The Concept of Law, Raz and Bulloch (eds) (Oxford: Clarendon Press, 2nd ed, 1994) p vii.

2 Some commentators have suggested that the contemporary history of jurisprudence amounts to little more than a series of extended footnotes, illustrative appendices and critical commentaries on Hart's The Concept of Law. One pundit went so far as to describe the first edition as 'probably the best book in legal philosophy ever written.': Murphy, Kant: The Philosophy of Right (London: Macmillan, 1970) p 180. Of course, the secondary literature on Hart's writings is voluminous. For more thorough and insightful books, see MacCormick, H.L.A. Hart (London: Edward Arnold, 1981); Martin, The Legal Philosophy of H.L.A. Hart: A Critical Perspective (Philadelphia: Temple University Press, 1987); and Bayles, Han's Legal Philosophy (Boston: Kluwer Academic, 1992).

3 The postscript is more of a supplement than a reworking: it is almost exclusively concerned with rebutting various interpretations, allegations and criticisms. Hart is more concerned with clarifying his previous ideas, not revising them. As such, Ido not intend to make separate reference to the postscript but will incorporate its arguments into my general account of Hart's work.

4 Hart, op cit n I, at p 275.

5 ibid $\mathrm{p} 128$

6 The first was about the extent to which the criminal law should enforce prevailing standards of morality: see Devlin, The Enforcement of Morals (Oxford: Oxford University Press, 1965) and Hart, Law, Liberty and Morality (Stanford: Stanford University Press, 1963). The second was about whether a moral criterion is essential to the validity of law properly defined: see Hart, 'Positivism and the Separation of Law and Morals' (1958) 71 Harvard L Rev 593; Fuller, 'Positivism and Fidelity to Law - A Reply to Professor Hart' (1958) 71 Harvard L Rev 630; and Fuller, The Morality of Law (New Haven: Yale University Press, 1964).

7 Hart, op cit $\mathrm{n} 1$, at $\mathrm{p} 259$.

8 See Austin, The Province of Jurisprudence Determined, Hart (ed) (London: Weidenfeld and Nicolson, 1954), and Bentham, Of Laws in General, Hart (ed) (London: Athlone Press, 1970).

9 Hart, op cit $\mathrm{n} \mathrm{I}$, at $\mathrm{p} 244$. For instance, unlike Hart, Dworkin takes an internal viewpoint on the question of the existence and applicability of law: see Dworkin, Law's Empire (Cambridge, Mass: Belknap Press, 1986) pp 65-94. For a general discussion of this problem, see Mandel, 'Dworkin, Hart and the Problem of Theoretical Perspective' (1979) 14LSR.

10 Hart, op cit $\mathrm{n} 1$, at $\mathrm{p} 269$.

11 ibid $\mathrm{p}$ 90. Hart's reliance on 'rules' is part of a broader post-World War II sociological tendency to understand social behaviour as basically rule-based: see Edgerton, Rules, Exceptions and Social Order (Berkeley: University of California Press, 1985)

12 Hart, op cit $\mathrm{n} 1$, at $\mathrm{p} 127$.

13 See Hart, 'American Jurisprudence Through English Eyes: The Nightmare and the Noble Dream' (1977) 11 Georgia L Rev 969, at p 989.

14 Hart, op cit n 1, at p 124. Like Hart, I will use 'rule application' to refer to what judges and lawyers do, and use 'rule following' to refer to what citizens (including lawyers and judges in their civic lives) do.

15 ibid $\mathrm{p}$ 125. See generally Hart, op cit $\mathrm{n}$ 13, at $\mathrm{p}$ 989; op cit $\mathrm{n} \mathrm{6}$, at pp 606-607; and 'Problems of the Philosophy of Law' in Hart (ed), Essays in Jurisprudence and Philosophy (Oxford: Clarendon Press, 1983) p 144.

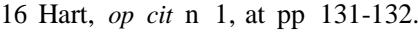

17 ibid $\mathrm{p} 80$.

18 ibid $\mathrm{p} 135$.

19 Hart, op cit $\mathrm{n} 15$, at $\mathrm{p} 107$.

20 Hart, op cit $\mathrm{n} 1$, at $\mathrm{p} 124$.

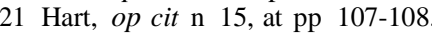

22 Hart, $o p$ cir n 1, at p 262. Jn this he follows Raz's defence of positivism against Dworkin's writings: see Raz, 'Legal Principles and the Limits of Law' (1972) 81 Yale LJ 823, at pp 832-834.

23 ibid $\mathrm{p} 274$.

24 ibid $\mathrm{p} 275$.

25 ibid $\mathrm{p} 123$

26 Hart, op cit $\mathrm{n}$ 6, at $\mathrm{p}$ 629; op cit $\mathrm{n} \mathrm{1,} \mathrm{at} \mathrm{p}$ 108. Although originally written in 1967, these latter words and ideas were republished unchanged in 1983. In 1961 (and, therefore, again in 1994), he noted that rule application will work 'smoothly ... over the great mass of ordinary cases': Hart, op cit $\mathrm{n} \mathrm{1,} \mathrm{at} \mathrm{p} 124$.

27 Hart, op cit $\mathrm{n} \mathrm{1,} \mathrm{at} \mathrm{pp} \mathrm{251-252.}$

28 Hart, op cit $\mathrm{n} 6$, at $\mathrm{p} 615$.

29 Hart, op cit n 15, at $\mathrm{p} 108$.

30 Dworkin, op cit $\mathrm{n} 9$, at $\mathrm{p} 352$.

31 Posner, The Problems of Jurisprudence (Cambridge, Mass: Harvard University Press, 1990) p 437.

32 For a critical survey of these different approaches, see Hutchinson, Waiting for Coraf. A Critique of Law and Rights (Toronto: University of Toronto Press, 1995) pp 20-30.

33 See Raz, The Concept of a Legal System (Oxford: Clarendon Press, 2nd ed, 1980), and Green, 'The Political Content of Legal Theory' (1987) 17 Philosophy and Social Sciences 15. For a recent attempt to defend a version of positivism that includes issues of political morality in the determination of legal 
validity, see Waluchow, Inclusive Legal Positivism (Oxford: Clarendon Press, 1994).

34 Scalia, 'The Rule of Law as a Law of Rules' (1989) 56 Chicago L Rev 1175, at p 1179.

35 MacCormick, 'The Ethics of Legalism' (1989) 2 Ratio Juris 184, at p 188. Other prominent fearmongers are Fuller, The Morality of I.aw (New Haven: Yale University Press, 1969) p 39; Fiss, 'Objectivity and Interpretation' (1982) 34 Stanford L Rev 739, at p 749; Edwards, 'The Judicial Function and the Elusive Goal of Principled Decisionmaking' [1991] Wisconsin L Rev 837, at pp 838-841; and Scalia, op cit $\mathrm{n} 34$, at $\mathrm{p} 1182$.

36 Tushnet, 'Does Constitutional Theory Matter? A Comment' (1987) 65 Texas L Rev 777, at p 782. For a fuller account of this position, see Singer, 'The Player and the Cards: Nihilism and Legal Theory' (1984) 94 Yale LJ I.

37 I have to confess that I have occasionally allowed a debilitating nihilism to get the better of my sceptical self: see Hutchinson, Dwelling on the Threshold: Critical Essays in Modern Legal Thought (Toronto: Carswell, 1988). This essay marks an explicit effort to retain and enhance critical theorising by distancing it from any nihilistic tendency. See Mootz, 'Rethinking the Rule of Law: A Demonstration that the Obvious is Plausible' (1993) 61 Tennessee L Rev 69, and 'Is the Rule of Law Possible in a Postmodern World?' (1993) 63 Washington L Rev 249.

38 Wittgenstein, Philosophical Investigations (trans, Anscombe; Oxford: Basil Blackwell, 1953) I, s 38.

39 See Austin, Philosophical Papers, Urmson and Warnock (eds) (Oxford: Clarendon Press, 1961) p 182 ('words are not (except in their own little corner) facts or things: we need therefore to prise them off the world, to hold them apart from and against it, so that we can realise their inadequacies and arbitrariness'); and Ryle, The Theory of Meaning (1963) p 144 ('the meaning of an expression is the role it is employed to perform, not any thing or person or event for which it might be supposed to stand').

40 Hart, 'Definition and Theory in Jurisprudence' in Hart (ed), Essays in Jurisprudence and Philosophy (Oxford: Clarendon Press, 1983) p 31. A similar step had been taken by Hohfeld in 1920, stating that 'attempts at formal definition are always unsatisfactory, if not altogether useless': see Hohfeld, Fundamental Legal Conceptions (New Haven: Yale University Press, 1964) p 35. For another effort to follow the linguistic turn through to law, see Williams, 'Language and the Law' (1945) 61 LQR 71, at pp 179, 293, 384; (1946) LQR 387. For a sympathetic rejoinder to this lecture, see Shuman, 'Jurisprudence and the Analysis of Fundamental Legal Terms' (1956) 8 JLE 437.

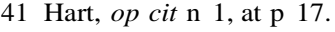

42 ibid $\mathrm{p} 125$.

43 ibid.

44 ibid.

45 Hart, op cit n 6, at pp 606-607.

46 Hart, op cil n 40, at pp 23,31.

47 Hart, op cil n I, at p 99.

48 Hart, op cit $\mathrm{n} 40$, at $\mathrm{p} 47$.

49 See p 802 below. Hart is caught between the 'picture' theory of the early Wittgenstein and the 'functional' scepticism of the later Wittgenstein: see Pears, Wittgenstein (London: Fontana, 1970).

50 Hart, op cit $\mathrm{n} \mathrm{I}$, at $\mathrm{p} 125$.

51 Derrida, Specters of Marx: The State of the Debt, the Work of Mourning and the New International (trans, Kamuf; London: Routledge, 1994) p xvii. Combining the insights of Wittgenstein and Derrida in a sceptical account of law is a risky but exciting prospect. However, while they derive from different traditions and write in a very different style, they are complementary in the important sense that they both maintain that the key to philosophy is language, they both are thoroughly sceptical about the possibility of a totalising metaphysics, and they both hold that meaning is undecidable and unclosable: see Garver and Lee, Derrida and Wittgenstein (Philadelphia: Temple University Press, 1994). The crucial difference is that, whereas Wittgenstein found it sufficient to contextualise language, Derrida challenges the stability of such contextualisations: see Derrida, Limited Inc (trans, Weber; Evanston, Ill: Northwestern University Press, 1988); see p 804 below.

52 Wittgenstein, op cit n 38, at I, s 109 ('philosophy is the bewitchment of our intelligence by means of language'). For a critical survey of this philosophical manoeuvre, see Rorty, The linguistic Tum: Recent Essays in Philosophical Merhod (Chicago: University of Chicago Press, 1967) p 3.

53 Wittgenstein, op cit n 38, at I, s 192. See Quine, From a Logical Point of View (Cambridge, Mass: Harvard University Press, 2nd ed, 1961) p 20; and Putnam, Realism with a Human Face (Cambridge, Mass: Harvard University Press, 1990).

54 Shakespeare, Romeo and Juliet, Act I, sc IV.

55 Wittgenstein, op cit $\mathrm{n} 38$, at I, s 241 and s 23. This is what accounts for his remark that 'if a lion could talk, we could not understand him': ibid II, xi, p 223.

56 This conclusion is far from original, but its full import has not been acknowledged: see, for example, Cohen, 'Field Theory and Judicial Logic' (1950) 59 Yale U 238, at p 240.

57 For a defence of the claim that scepticism is not relativistic because relativism is simply one more version of truth-stating which scepticism rejects, see Rorty, 'Solidarity or Objectivity?' in Rajchman and West (eds), Post-Analytic Philosophy (New York: Columbia University Press, 1985).

58 Hart, op cit $\mathrm{n} 1$, at $\mathrm{p} 103$.

59 Derrida rejects the use of 'indeterminacy' and prefers 'undecidability.' However, because indeterminacy is a common term in jurisprudential argot and because I use it in the same way that Derrida uses undecidability, I have decided to retain with indeterminacy: see Derrida, Limited Inc (trans, Weber; 
Evanston, Ill: Northwestern University Press, 1988) p 148. For a contrary reading to my own, see Winter, 'For What It's Worth' (1992) 26 LSR 789, at pp 810-812.

60 See Kress, 'Legal Indeterminacy and Legitimacy' in Leyh (ed), Legal Hermeneutics: History, Theory and Practice (Berkeley: University of California Press, 1992) p 201.

61 See Fish, 'Play of Surfaces: Theory and the Law' in Leyh (ed), Legal Hermeneutics: History, Theory and Practice (Berkeley: University of California Press, 1992) p 302. See also Hutchinson, 'Democracy and Determinacy: An Essay on Legal Interpretation' (1989) 43 Univ Miami L Rev; and 'Blurred Visions: The Politics of Civil Obligation' in Cooper-Stephenson and Gibson (eds), Torr Theory (Toronto: Captus University Publications, 1993) pp 276-311.

62 Binder, 'Beyond Criticism' (1988) 55 Univ Chicago L Rev 888; and Hutchinson, 'Blurred Visions,' op cit $\mathrm{n} 61$, at $\mathrm{p} 43$.

63 See Fish, Doing What Comes Naturally (London: Duke University Press, 1989) p 503.

64 Hart, op cit n 1, at p 126.

65 ibid $\mathrm{p} \mathrm{129.} \mathrm{See} \mathrm{Fuller,} \mathrm{op} \mathrm{cit} \mathrm{n} \mathrm{6,} \mathrm{at} \mathrm{p}$ 663. Schauer and Brink agree that when a police car enters the park, the question is not whether a police car is a vehicle but whether it is desirable to exclude it from the park. On the question of what follows from a finding that something is or is not a vehicle, see $\mathrm{p} 810$ below. Whereas Brink concludes that 'on almost any semantic theory ... "vehicle" clearly includes police car, ' ('Legal Theory, Legal Interpretation and Judicial Review' (1988) 17 Philosophy and Public Affairs 105, at p 124), Schauer contends that 'the rule is literally violated by the police car': 'Rules and the Rule-Following Argument' (1990) 3 Canadian J Law and Jurisprudence 187, at p 188. How does a car violate a rule? What is so literal about it?

66 See Lay, Ways of the World: A History of Roads and Vehicles (New Brunswick, NJ: Rutgers University Press, 1992) p 184. A bicycle has been considered both inside and outside the definition of 'vehicle' for the purposes of determining whether its rider is subject to the statutory rules of the road. In Oklahoma of 1915 it was (see Tulsa Ice Co v Wilkes (1915) 152 P 1169); in Maine of 1964 it was not (see Fowles v Dakin (1964) 205 A 2d 169). However, in Maryland of 1975 it was again (see Richards v Goff (1975) 338 A 2d 80).

67 See White v District of Columbia (1925) 4 F 2d 163.

68 State v One Black Horse Mule (1922) 92 So 548; Stanley v Tomlin (1925) 129 SE 379.

69 Greenawalt, 'How Law can be Determinate' (1990) 38 UCLA L Rev 1, at p 12. See also Sunstein, 'Analogical Reasoning' (1992) 105 HLR 741.

70 This is quoted in Backer and Hacker, Wittgenstein: Rules, Grammar and Necessity (Oxford: Basil Blackwell, 1985) p 258, and is drawn from one of Wittgenstein's unpublished manuscripts, Zettel.

71 MacCormick, Legal Reasoning and Legal Theory (Oxford: Clarendon Press, 1978) p 197.

72. ibid $\mathrm{p}$ 132. For a strong defence of Hart and reaffirmation of this positivist commitment, see Marmor, 'No Easy Cases?' (1990) 2 Canadian J Law and Jurisprudence 61.

73 Hart, op cit $\mathrm{n} \mathrm{I}$, at pp 251-252.

74 See p 792 above.

75 Derrida, op cit $\mathrm{n} 51$, at $\mathrm{p} 147$.

76 Wittgenstein, op cit n 38, at I, s 145.

77 Wittgenstein, Zettel, Anscombe and von Wright (eds) (Cambridge, Mass: Harvard University Press, 1967) p 303. Picking up on Wittgenstein's ideas, Kripke argues persuasively that it is impossible to establish an authoritative set of philosophical criteria that can test whether a rule is or is not being followed: see Kripke, Wittgenstein on Rules and Private Language (Cambridge, Mass: Harvard University Press, 1982); and also Yablon, 'Law and Metaphysics' (1987) 96 Yale U613, at p 633. In the jurisprudential literature, the tendency has been to deploy Wittgensteinian wisdom to underwrite rather than undermine the positivist project: see Bix, 'The Application (and Mis-Application) of Wittgenstein's Rule-Following Considerations to Legal Theory' (1990) 2 Canadian J Law and Jurisprudence 107; Schauer, 'Rules and the Rule-Following Argument' (1990) 2 Canadian J Law and Jurisprudence; and Landers, 'Wittgenstein, Realism and CLS: Undermining Rule Scepticism' (1990) 9 Law and Philosophy 177.

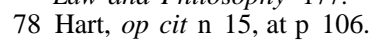

79 See Schauer, 'Easy Cases' (1985) 58 Southern California L Rev 399; and Dworkin, op cit $\mathrm{n}$ 9, at pp $351,352$.

80 See Greenawalt, op cit n 69, at p 31; see also Kress, op cit n 60.

81 On weird and outrageous cases, see Tushnet, 'A Note on the Revival of Textualism in Constitutional Theory' (1985) 58 Southern California L Rev 683, at $\mathrm{p}$ 688; and D'Amato, 'Aspects of Deconstruction: The Easy Case of the Under-Aged President' (1989) 84 Northwestern Univ L Rev

250. Even 'under present social conditions' it might be possible to bring nose-scratching within the crime of theft, at least if this includes accessories before the fact $-\mathbf{a}$ thief's accomplice might use a nose-scratch as the signal that the coast is clear. For an early challenge to 'easy cases' that takes a different tack to my own, see Conklin, 'Clear Cases' (1981) 31 Univ Toronto LJ 231.

82 Fuller, op cit n 6, at p 663.

83 See Hutchinson, op cit n 32, at pp 32-39. There is a rich history in the English common law of judges making what appear to be counter-intuitive and bizarre findings. When almost all petty thefts were punishable by mandatory capital punishment, judges resorted to all kinds of odd distinctions and interpretations to avoid the imposition of draconian penalties: see Hay, 'Property, Authority and Criminal Law' in Hay et al (eds), Albion's Fatal Tree (New York: Pantheon Books, 1977) pp 17-64. It is not difficult to imagine a repressive regime of the future in which a similar legal sophistry would 
hopefully arise: see, for example, Attwood, A Handmaid's Tale (Toronto: McClelland and Stewart, 1985).

84 Hart, op cit $\mathrm{n} \mathrm{I}$, at $\mathrm{p} 139$. This topic is deserving of an article of its own. 85

Duport Steels Ltd v Sirs (1980] 1 WLR 142, per Lord Scarman

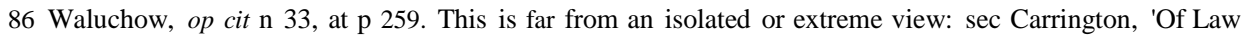
and the River' (1984) 34 JLS 227; and Fiss, 'The Death of Law?' (1986) 72 Cornell L Rev I.

87 Schauer, Playing by the Rules: A Philosophical Examination of Rule-Based Decision-Making in Law and in Life (Oxford: Clarendon Press, 1991) p 192.

88 See Derrida, Of Grammatology (Baltimore: Johns Hopkins University Press, 1976) p 24; and Fish, op cit n 61. In so far as Gilligan's writings remain pertinent, this notion of relational context pushes the traditional thinking about rule application away from the male virtues to the female ones: see Gilligan, In a Different Voice (Cambridge, Mass: Harvard University Press, 1982).

89 ibid p 244. For an illuminating investigation of this requirement, see Hill, 'H.L.A. Hart's Hermeneutic Positivism: On Some Methodological Difficulties in the Concept of Law' (1990) I Canadian J Law and Jurisprudence 113.

90 Hart, op cit $\mathrm{n} 1$, at $\mathrm{p} 91$.

91 Radin, 'Reconsidering the Rule of Law' (1989) 69 Boston Univ L Rev 781.

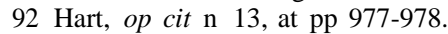

93 Fish, 'Rhetoric' in Lentricchia and McLaughlin (eds), Critical Termsfor literary Study (Chicago: University of Chicago Press, 1990) p 214.,

94 See Polanyi, Personal Knowledge (Chicago: University of Chicago Press, 1962).

95 Llewellyn, 'The Adventures of Rollo' (1952) 2 Univ Chicago Law School Record 3, at p 23.

96 Rony, 'Feminism and Pragmatism' (1990) 30 Michigan Quanerly Rev 231, at p 239.

974 Quintilian, Jnstitutio Oratorio, Book XII, s I.I (trans, Butler; Cambridge, Mass: Harvard University Press, 1961).

98 See Dworkin, op cit n 9, at p 401; and Fuller, op cit n 6, at p 668, quoting Omychund v Barker (1744) 26 ER 15, at p 22.

99 Bunon, Judging in Good Faith (Cambridge: Cambridge University Press, 1992) p 237. See also Kellogg, 'Legal Scholarship and the Temple of Doom: Pragmatism's Response to Critical Legal Studies' (1990) 65 Tulane L Rev 15, at p 18 ('It is one thing to sack the temple; it is another to don the stolen robes').

100 Goodrich, Reading the Law: A Critical Introduction to Legal Method and Techniques (Oxford: Basil Blackwell, 1986) p 216.

101 See Rony, op cit $\mathrm{n} 96$, at $\mathrm{p} 254$.

102 As quoted in American Soc Etc v Murray Comms Inc (1982) 547 F Supp 462 (ND Ill).

103 Hart, op cit $\mathrm{n}$ 6, at p 614. For a similar complaint, see Fuller, op cit n 6, at pp 663-664. 104

Hart, op cit $\mathrm{n} 1$, at $\mathrm{p} 141$.

105 ibid $\mathrm{p} 139$.

106 Connolly, Identity/Difference: Democratic Negotiations of Political Paradox (Ithaca: Cornell University Press, 1991) p x. See also Derrida, 'Afterword' in Limited Inc (Evanston, Ill: Northwestern University Press, 1988); and Posner, Overcoming Law (Cambridge, Mass: Harvard University Press, 1995). This understanding of law draws on Heraclitus' idea that 'justice is strife': see Robinson (ed), Fragments (Paris: Paris University Press, 1987) p 49. For a preliminary attempt to pursue this agonistic account of law, see Hutchinson, 'Playing the Game' (1994) 17 Dalhousie U 263.

107 Carse, Finite and Infinite Games: A Vision of Life as Play and Possibility (Harmondsworth: Penguin, 1986) p 149.

108 Hart, op cit $\mathrm{n} 40$, at $\mathrm{p}$ I. 